\title{
Analysis of Ca-PZT powder obtained by the Pechini and partial oxalate methods
}

\section{(Análise do pó de PZT-Ca obtido pelo método Pechini e método do oxalato parcial)}

\author{
R. S. Nasarl, M. Cerqueira ${ }^{1}$, E. Longo ${ }^{2}$, J. A. Varela ${ }^{3}$ \\ ${ }^{I}$ Departamento de Química, UFRN, Natal, RN, 59072-970 \\ ${ }^{2}$ Departamento de Química, UFSCar, Rod. Washington Luiz, km 235, S. Carlos, SP 13565-905 \\ ${ }^{3}$ Instituto de Química, UNESP, Araraquara, SP 14800-900 \\ nasar@terra.com.br
}

\begin{abstract}
$\mathrm{Ca}-\mathrm{Pb}(\mathrm{Zr}, \mathrm{Ti}) \mathrm{O}_{3}(\mathrm{Ca}-\mathrm{PZT})$ powders were prepared by a combined method, Pechini technique for the intermediate $\mathrm{ZrTiO}_{4}(\mathrm{ZT})$ particles and oxalate route for the final powder. The intermediate and final products were characterized by X-ray diffraction and BET for phase identification and granulometric analysis, respectively. The surface area of ZT powder reduced remarkably from 70 to $7.4 \mathrm{~m}^{2} / \mathrm{g}$ when the calcining temperature increased from 600 to $800{ }^{\circ} \mathrm{C}$. Incremental pore volume and average pore diameters of the powder calcined at $700{ }^{\circ} \mathrm{C}$ for $3 \mathrm{~h}$ were $0.026 \mathrm{~cm}^{3} / \mathrm{g}$ and $70 \AA$, respectively. Ca-PZT powder calcined at $800{ }^{\circ} \mathrm{C}$ for $3 \mathrm{~h}$, with agglomeration factor (AF) 2.8, showed no hysteresis in BET analysis, which indicate small agglomeration without micropores among particles. The powder calcined at $750{ }^{\circ} \mathrm{C}$ for $3 \mathrm{~h}$, however, exhibited small AF and high sinterability.
\end{abstract}

Keywords: Pechini method, Ca-PZT, powder sintering.

\section{Resumo}

Pós de $\mathrm{Ca}-\mathrm{Pb}(\mathrm{Zr}, \mathrm{Ti}) \mathrm{O}_{3}(\mathrm{Ca}-\mathrm{PZT})$ foram preparados por um método combinado que consiste na técnica Pechini para as partículas intermediárias de $\mathrm{ZrTiO}_{4}(\mathrm{ZT})$ e a rota do oxalato para o pó final. Os produtos intermediário e final foram caracterizados por difração de raios $X$ e determinação de área de superficie especifica pelo método BET, respectivamente. A área de superfície especifica do pó de ZT reduz bastante de 70 para $7,4 \mathrm{~m}^{2} / \mathrm{g}$ com o aumento da temperatura de calcinação de 600 para $800{ }^{\circ} \mathrm{C}$. $O$ volume incremental de poros e os diâmetros médios de poros do pós calcinado a $700{ }^{\circ} \mathrm{C} / 3 \mathrm{~h}$ forma $0,026 \mathrm{~cm}^{3} / \mathrm{g} 470 \mathrm{~A}$, respectivamente. $O$ pós de Ca-PZT calcinado a $800^{\circ} \mathrm{C} / 3 \mathrm{~h}$, com fator de aglomeração 2,8, não apresentou histerese na análise de BET, o que indica pequea aglomeração sem micriporos entre as partículas. O pó calcinado a $750^{\circ} \mathrm{C} / 3 \mathrm{~h}$, contudo, apresentou pequeno fator de aglomeração e alta sinterabilidade.

Palavras-chave: método Pechini, Ca-PZT, sinterização de pós.

\section{INTRODUCTION}

Several synthesis methodologies [1-3] of lead zirconate titanate, $\mathrm{Pb}(\mathrm{Zr}, \mathrm{Ti}) \mathrm{O}_{3}$ - $\mathrm{PZT}$ were used to obtain high phase homogeneity, high surface area and a small level of powder agglomeration which lead to dense bodies and materials with high piezoelectric properties after sintering $[4,5]$. The chemical synthesis, such as co-precipitation [6], sol-gel [7] and others [8] could cause high agglomeration of precipitate powder or small size particles $(>50 \mathrm{~nm})$ that lead to a decrease in the powder sinterability.

An advantage of the Pechini method [9] is the nucleation of an amorphous powder with diameter of a few nanometers allowing growth and phases crystallization control.

Recent work $[10,11]$ used $\mathrm{ZrTiO}_{4}(\mathrm{ZT})$ as an intermediary phase in the PZT synthesis. High temperatures for the ZT phase formation [12] leads to the use of a chemical synthesis method that promotes decrease of temperature during the phase formation. As an example $\mathrm{Zr}_{\mathrm{x}} \mathrm{Ti}_{1-\mathrm{x}} \mathrm{O}_{4}$ at composition ranges among $0.35 \leq \mathrm{x} \leq 0.65$ was synthesized using the Pechini method with high phase homogeneity and small particle size distribution [13]. Different methods were used for the ZT phase synthesis, such as combination of the spray decomposition method with solid state reaction [14] and partial oxalate $(\mathrm{PbO})$ with hydrothermal reaction $(\mathrm{ZT})$ [15].

Compositional fluctuation in PZT near the morphotropic phase boundary (MPB) $[16,17]$ region is caused by Ti and $\mathrm{Zr}$ ions migration due to microregions of different chemical potentials. Non-stoichiometric conditions could occur due to high loss of $\mathrm{PbO}[18]$ during calcination and sintering stages. $\mathrm{PbO}$ loss during the calcination and sintering stages $[19,20]$ of the PLZT phase leads to the use of a synthesis process 
that causes a minimum evaporation effect. Thus, a diffusion process by interfaces decreases the $\mathrm{PbO}$ volatilization during the heating stages. The $\mathrm{PbO}$ phase obtained by partial oxalate method with decomposition onto the ZT particles decreases such effect due to the diffusion process that occur at low temperatures. $\mathrm{PbC}_{2} \mathrm{O}_{4}$ was decomposed on ZT surface particles to obtain niobium doped lead zirconate titanate, PZTN at $650{ }^{\circ} \mathrm{C} / 6 \mathrm{~h}$ [15]. Densities close to the theoretical values were obtained after sintering. Different precipitation routes were used [21] and grain sizes close to $2.0 \mu \mathrm{m}$ were obtained by sintering at $1200^{\circ} \mathrm{C} / 2.5 \mathrm{~h}$. PLZT was sinthesized by precipitation of $\mathrm{PbC}_{2} \mathrm{O}_{4}$ on ZT particles to obtain a calcined powder with $2.2 \mu \mathrm{m}$ of diameter [11].

Small significance has been done for substitutions of calcium in PZT due to a strong powder agglomeration tendency that degrades all properties of the sintered material. Synthesis by precipitation of calcium in PZT [22] shows powders with strong agglomeration level. Agglomeration with low surface area caused a degradation of the ferroelectric and piezoelectric properties. $\mathrm{Pb}$ partially replaced by $\mathrm{Ca}$ or $\mathrm{Sr}$ [23] shows better properties than the PZT with $1 \mathrm{~mol} \%$ of calcium substitutions.

The purpose of the present work is to synthesize and analyze the powder characteristics of Ca-PZT using two processing methods: the Pechini for ZT and the partial oxalate for Ca-PZT.

\section{EXPERIMENTAL}

High purity raw materials, zirconium IV propoxide, titanium IV isopropoxide, $\mathrm{Pb}\left(\mathrm{NO}_{3}\right)_{2} \cdot 6 \mathrm{H}_{2} \mathrm{O}$ and $\mathrm{Ca}\left(\mathrm{NO}_{3}\right)_{2} \cdot 5 \mathrm{H}_{2} \mathrm{O}$ were used for the synthesis of $\mathrm{Pb}_{0.95} \mathrm{Ca}_{0.05}\left(\mathrm{Zr}_{0.53} \mathrm{Ti}_{0.47}\right) \mathrm{O}_{3}$ solid solutions.

\section{ZT synthesis by the Pechini method}

Stoichiometric mixture of titanium IV isopropoxide, zirconium IV propoxide in citric acid and water $(80 / 20$ vol. $\%$ ) were prepared at $90{ }^{\circ} \mathrm{C}$ at concentrations of $7.4 \% \mathrm{TiO}_{2}$ of Ti citrate solution and $7.1 \% \mathrm{ZrO}_{2}$ of $\mathrm{Zr}$ citrate solution. A mixture of resins with a stoichiometry of $0.47 \mathrm{~mol} \%$ of $\mathrm{TiO}_{2}$ and $0.53 \mathrm{~mol} \%$ of $\mathrm{ZrO}_{2}$ was prepared at $100{ }^{\circ} \mathrm{C}$. After homogenization, ethylene glycol was added at a mass ratio of 40/60 relative to the citric acid. A rigid polymeric resin obtained at $250{ }^{\circ} \mathrm{C} / 2 \mathrm{~h}$ was decomposed and ground in a ball mill, calcined for $3 \mathrm{~h}$ at different temperatures and characterized by XRD and BET.

\section{Ca-PZT synthesis by the partial oxalate method}

The ZT particles were dispersed in water under stirring. Stoichiometric amount of lead nitrate $(0.995 \mathrm{~mol} \%)$ and calcium nitrate $(0.005 \mathrm{~mol} \%)$ were dissolved in the solution. A precipitation of $\mathrm{PbC}_{2} \mathrm{O}_{4}$ and $\mathrm{CaC}_{2} \mathrm{O}_{4}$ on the $\mathrm{ZT}$ surface occurs by addition of $\mathrm{NH}_{4} \mathrm{OH}$. The precipitated product was washed, filtered and dried in an oven at $70^{\circ} \mathrm{C}$. The powder was ground, sieved at $325 \mathrm{mesh}$, calcined in the temperature range $350-800{ }^{\circ} \mathrm{C}$ for $3 \mathrm{~h}$ and characterized by XRD and BET.

\section{RESULTS AND DISCUSSION}

Fig. 1 shows $\mathrm{X}$-ray diffraction patterns of the ZT (53/47) powder calcined from $350{ }^{\circ} \mathrm{C}$ to $700{ }^{\circ} \mathrm{C} / 3 \mathrm{~h}$ with intense peaks of the crystalline phase at $700{ }^{\circ} \mathrm{C}$. During the decomposition of the polymeric resin of citrates, an increase of the ZT crystalline phase up to $600{ }^{\circ} \mathrm{C}$ is observed. Comparison among processes, such as solid-state reaction [1], precipitation [2] and others [3] demonstrated that high temperature is necessary for the ZT phase formation. The ZT phase was synthesized using a polymeric precursor method observing high crystallinity close to $700{ }^{\circ} \mathrm{C}[5,21]$.

Surface area of the ZT crystalline powder was remarkably reduced from 70 to $7.4 \mathrm{~m}^{2} / \mathrm{g}$ with 600,700 and $800{ }^{\circ} \mathrm{C}$ calcination temperatures. The particle growth occurs when an increase of intensity of the $2 \theta=37^{\circ}$ peak is observed.

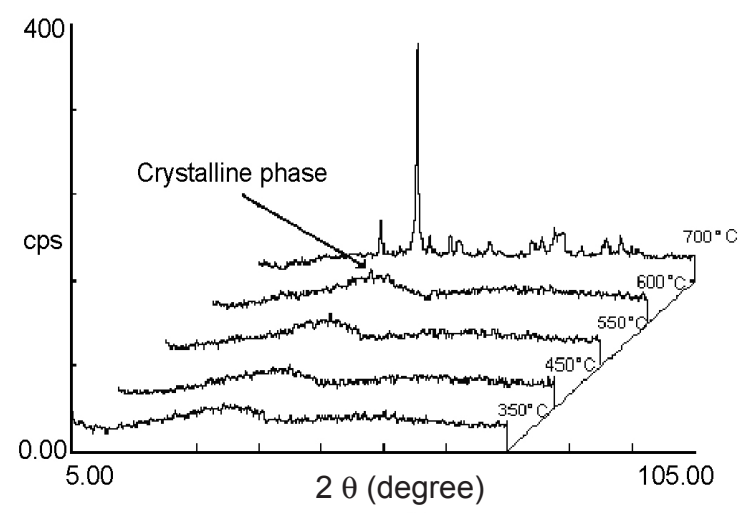

Figure 1: X-ray diffraction pattern of the ZT (53/47) phase. [Figura 1: Difração de raios X da fase ZT (53/47).]

Fig. 2 shows the characteristic curves of adsorption/ desorption of ZT powders calcined at 600 and $700{ }^{\circ} \mathrm{C}$ with a hysteresis formation. A hysteresis $\mathrm{H}$ type II (bottle shape) and isotherm IV type at $600{ }^{\circ} \mathrm{C}$ indicated that microporosity

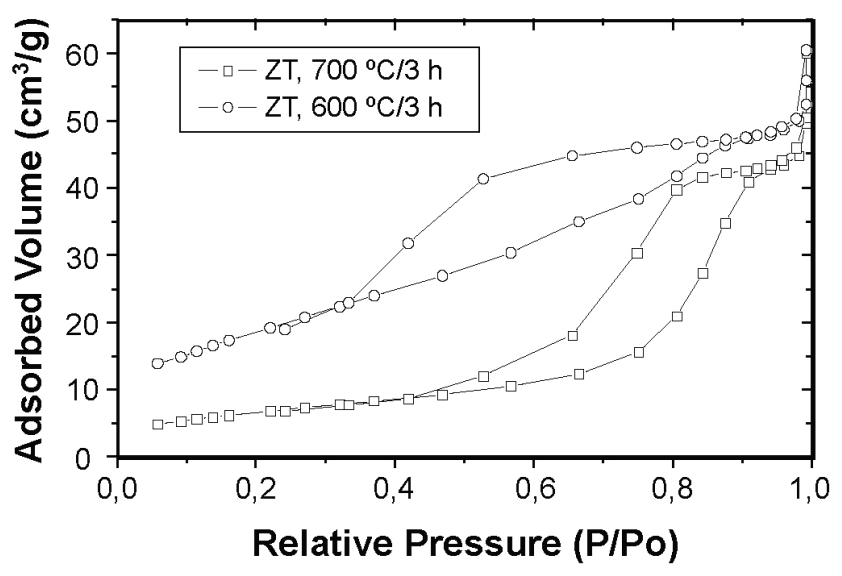

Figure 2: Adsorbed volume versus relative pressure of the ZT phase. Powder calcined at 600 and $700{ }^{\circ} \mathrm{C} / 3 \mathrm{~h}$.

[Figura 2: Volume adsorvido em função da pressão relativa da fase ZT. Pó calcinado a 600 e $700^{\circ} \mathrm{C} / 3 \mathrm{~h}$. ] 
$(\mathrm{r}<2 \mathrm{~nm})$ does not occur. At $700{ }^{\circ} \mathrm{C}$ a hysteresis $\mathrm{H}$ I type (cylindrical shape) and isotherm IV type was observed indicating open porosity.

Fig. 3 shows the incremental pore volume of the ZT powder calcined from $600{ }^{\circ} \mathrm{C}$ to $700{ }^{\circ} \mathrm{C}$ demonstrating a change of the average pore diameter from $35 \AA$ (at $600{ }^{\circ} \mathrm{C}$ ) to $55 \AA$ (at $700^{\circ} \mathrm{C}$ ) (mesopores) caused by an increase of the particle size with an increase of the pore volume. Volume adsorption of about $0.030 \mathrm{~cm}^{3} / \mathrm{g}$ indicated that a small agglomeration of nanoparticles took place.

Characterization of the Ca-PZT powders

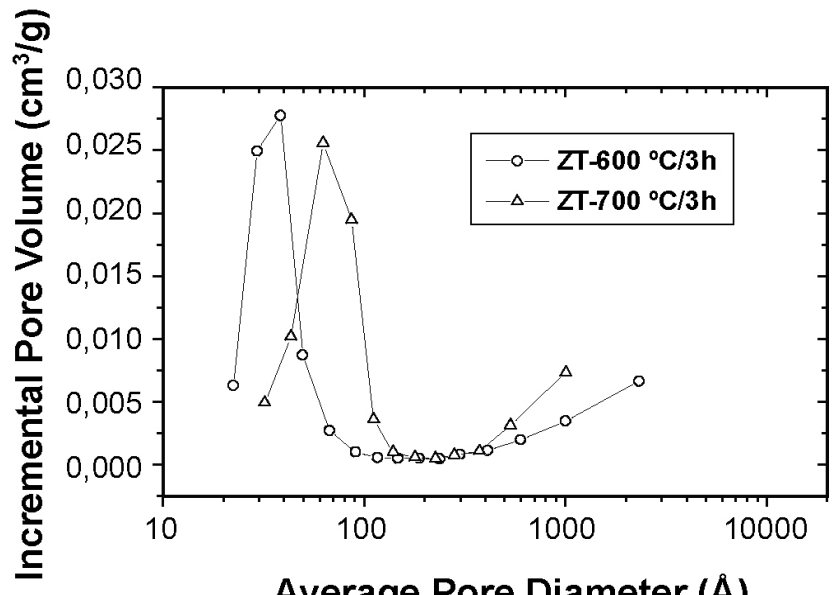

Figure 3: Incremental pore volume versus average pore diameter of the ZT phase.

[Figura 3: Volume incremental de poros em função do diâmetro de poros da fase ZT. ]

Fig. 4 shows the X-ray diffraction pattern of a monophasic solid solution of the Ca-PZT phase with tetragonal structure. According to several authors $[6,7]$ the compositional fluctuation of $\mathrm{Zr}$ and $\mathrm{Ti}$ ions occurs near the $\mathrm{Zr}$ concentrations between 50 and $53 \mathrm{~mol} \%$ in the phase diagram of PZT. Such range of the $\mathrm{Zr}$ concentrations caused a coexistence between a $\mathrm{F}_{\mathrm{T}}$ (ferroelectric tetragonal) and

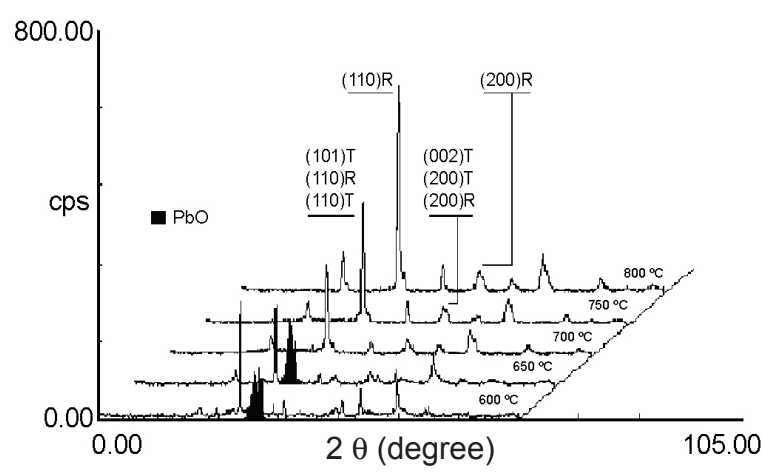

Figure 4: X- ray diffraction pattern of the Ca-PZT phase. [Figura 4: Difração de raios $X$ da fase Ca-PZT. ]
$F_{R}$ (ferroelectric rhombohedral) phase inside the MPB (morphotropic phase boundary). Calcium additions in PZT diminished the compositional fluctuation and dislocated from the MPB to $\mathrm{F}_{\mathrm{T}}$ phase ( $\mathrm{Zr}$ rich region).

An internal interface $\mathrm{ZT} / \mathrm{Ca}-\mathrm{PZT} / \mathrm{PbC}_{2} \mathrm{O}_{4}-\mathrm{CaC}_{2} \mathrm{O}_{4}$ was formed and a high surface area reduction from $25 \mathrm{~m}^{2} / \mathrm{g}$ (ZT phase) to $2 \mathrm{~m}^{2} / \mathrm{g}$ (Ca-PZT phase) at $600{ }^{\circ} \mathrm{C} / 3 \mathrm{~h}$ occurred.

Comparisons between particle sizes of the Ca-PZT phase using BET and XRD methods are shown in Table I, with an agglomeration factor $\left(\mathrm{AF}=\mathrm{D}_{\mathrm{BET}} / \mathrm{D}_{\mathrm{XRD}}\right)$ of 1.7 at $700^{\circ} \mathrm{C} / 3 \mathrm{~h}$ and 2.8 at $800{ }^{\circ} \mathrm{C} / 3 \mathrm{~h}$. The analysis shows that gas adsorption with two and three particles occurs, respectively, and demonstrate that the BET analysis data presents larger particle size compared with the crystallite size obtained by XRD. A small agglomeration of powder could be accepted considering that the XRD analysis shows a primary particle diameter in a specific crystalline direction.

Table I - Surface area, average particle size by BET and average particle size by XRD of calcined Ca-PZT powder.

[Tabela I - Área de superfície especifica, tamanho médio de partícula por BET e por difração de raios $X$ de pós de $\mathrm{Ca}$ PZT. ]

\begin{tabular}{lccccc}
\hline & $600{ }^{\circ} \mathrm{C}$ & $650{ }^{\circ} \mathrm{C}$ & $700{ }^{\circ} \mathrm{C}$ & $750{ }^{\circ} \mathrm{C}$ & $800{ }^{\circ} \mathrm{C}$ \\
\hline $\mathrm{A}_{\text {BET }}\left(\mathrm{m}^{2} / \mathrm{g}\right)$ & 3.20 & 2.95 & 2.42 & 2.28 & 1.08 \\
$\mathrm{D}_{\text {BET }}(\mathrm{nm})$ & 235.80 & 255.60 & 312.50 & 331.00 & 698.00 \\
$\mathrm{D}_{\text {XRD }}(\mathrm{nm})$ & 63.92 & 72.25 & 181.80 & 229.00 & 252.60 \\
\hline
\end{tabular}

Fig. 5 shows a hypothetical mechanism of the Ca-PZT phase formation consisting of a decomposition of $\mathrm{PbC}_{2} \mathrm{O}_{4}$ $\mathrm{CaC}_{2} \mathrm{O}_{4}$ with formation of $\mathrm{PbO}$ and $\mathrm{CaO}$ onto the $\mathrm{ZT}$ particle (surfaces of the particles). $\mathrm{Pb}$ and $\mathrm{Ca}$ ions migrate towards the ZT phase and the Ca-PZT phase is formed between two different phases ( $\mathrm{ZT}$ and $\mathrm{PbO}-\mathrm{CaO}$ ). Constant diffusion of $\mathrm{Pb}$ and $\mathrm{Ca}$ ions across the $\mathrm{Ca}-\mathrm{PZT}$ phase occurs and growth, such as towards the ZT phase as well as in the direction of $\mathrm{PbO}-\mathrm{CaO}$ phases .

Fig. 6 shows a hysteresis curve of $\mathrm{H} 2$ type and isotherm

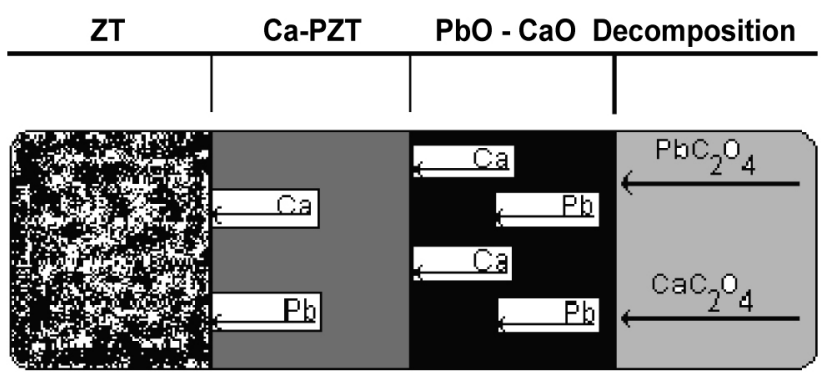

Growth of the Ca-PZT phase

Figure 5: Mechanism of the Ca-PZT phase formation. [Figura 5: Mecanisno da formação da fase Ca-PZT.] 
curve of type II (bottle shape pores) at $600{ }^{\circ} \mathrm{C} / 3 \mathrm{~h}$. Such characteristics demonstrate that an agglomeration between particles may be present and it is in agreement with the AF calculations. At $800{ }^{\circ} \mathrm{C} / 3 \mathrm{~h}$ an isotherm curve type II is observed and a small hysteresis behavior occurs. Such fact demonstrates that a large quantity of agglomerated particles reacts by a diffusion process, decreases the porosity and forms large particles.

Fig. 7 shows the incremental pore volume at $600{ }^{\circ} \mathrm{C} / 3 \mathrm{~h}$

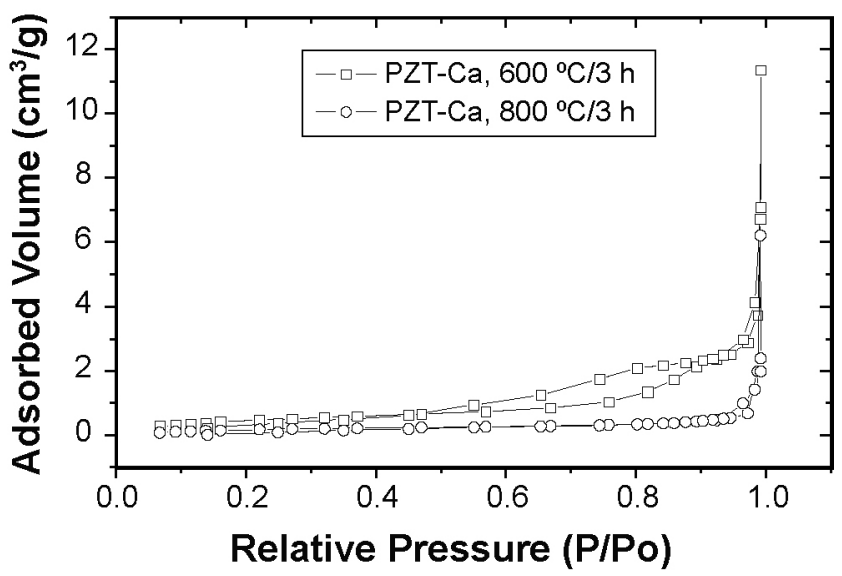

Figure 6: Adsorbed volume versus relative pressure of Ca-PZT phase. Powder calcined at 600 and $800{ }^{\circ} \mathrm{C} / 3 \mathrm{~h}$.

[Figura 6: Volume adsorvido em função da pressão relativa da fase Ca-PZT. Pó calcinado a 600 e $800^{\circ} \mathrm{C} / 3$ h.]

indicating that the presence of mesopores (30-100 $\AA$ ), indicating a rapid increase of porosity at $300 \AA$ characterizing macropores. Similar analysis of the powder at $800{ }^{\circ} \mathrm{C} / 3 \mathrm{~h}$ shows a rapid increase of pore volume above $300 \AA$ indicating growth of macroparticles (clusters) and shows a large increase of pore volume. However, particles (clusters) with small agglomeration level were densified and suppressed a residual porosity.

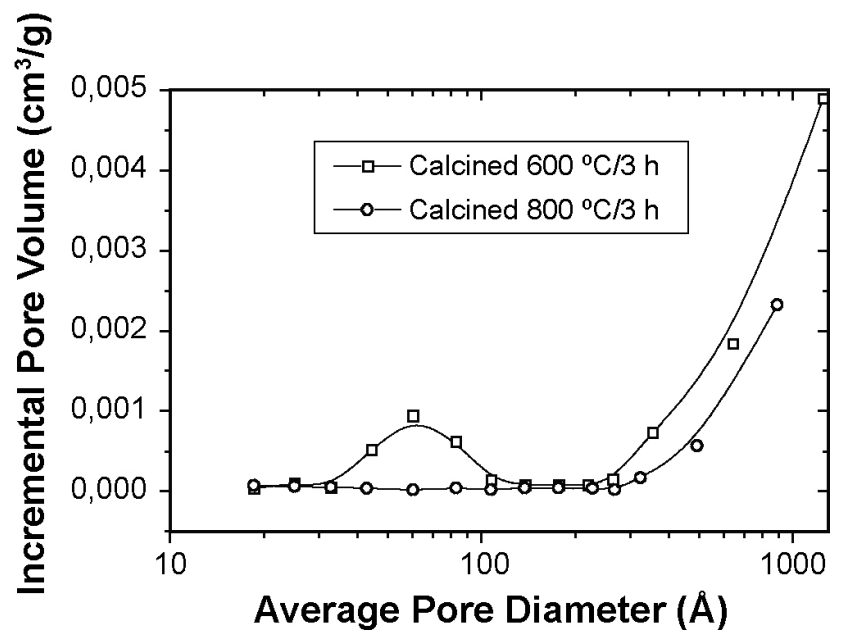

Figure 7: Incremental pore volume versus average pore diameter of the Ca-PZT phase. Powder calcined at 600 and $800{ }^{\circ} \mathrm{C} / 3 \mathrm{~h}$.

[Figura 7: Volume incremental de poro em função do diâmetro do poro da fase Ca-PZT. Pós calcinado a 600 e $800^{\circ} \mathrm{C} / 3$ h.]
Fig. 8 shows a kinetic analysis of particle growth of the $\mathrm{Ca}$ PZT phase. The straight lines show a change of slope above $700{ }^{\circ} \mathrm{C}$ indicating that a change of mass transport occurs. Below $700{ }^{\circ} \mathrm{C}$ a contact between particles of the powder due to agglomeration caused neck formation characterized by a non densifying mass transport mechanism, such as a surface diffusion process. A strong reduction of surface area by grain boundary diffusion or volume diffusion mechanisms is possible to occur.

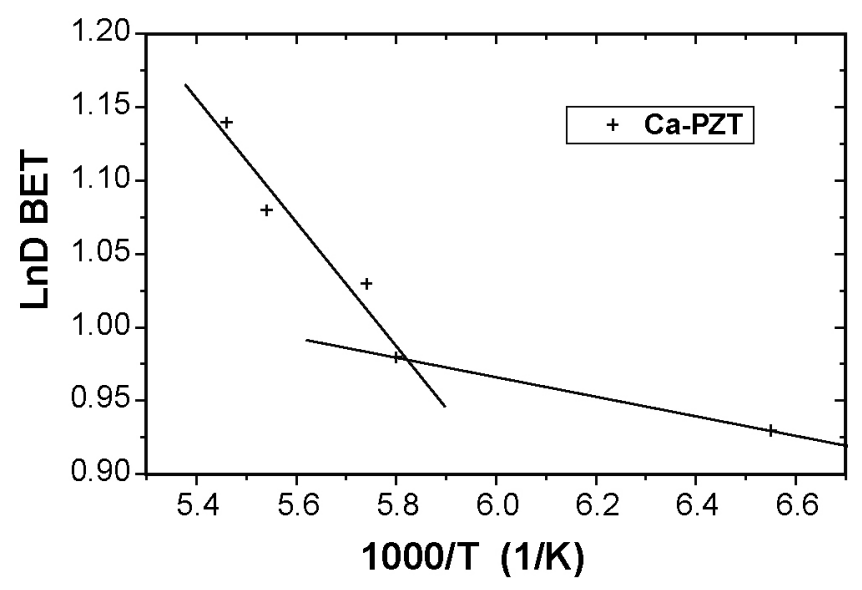

Figure 8: Dependence of the BET particle size on the teciprocal of the absolute calcination temperature of $\mathrm{Ca}-\mathrm{PZT}$ powder.

[Figura 8: Dependência do tamanho de partícula da fase Ca-PZT determinada por BET com o recíproco da temperatura absoluta de calcinação.]

\section{CONCLUSIONS}

The synthesis of the Ca-PZT powder by the Pechini and the partial oxalate methods promoted small agglomeration of powder for both ZT and Ca-PZT synthesis. Analysis by BET of the ZT phase shows high reduction of surface area from $70 \mathrm{~m}^{2} / \mathrm{g}$ at $600{ }^{\circ} \mathrm{C} / 3 \mathrm{~h}$ to $24.6 \mathrm{~m}^{2} / \mathrm{g}$ at $700{ }^{\circ} \mathrm{C} / 3 \mathrm{~h}$. CaPZT calcined at $700{ }^{\circ} \mathrm{C} / 3 \mathrm{~h}$ shows surface area $2.42 \mathrm{~m}^{2} / \mathrm{g}$. Agglomeration factor of 1.8 at $700{ }^{\circ} \mathrm{C} / 3 \mathrm{~h}$ and 2.8 at 800 ${ }^{\circ} \mathrm{C} / 3 \mathrm{~h}$ were determined. Hysteresis behavior indicated that agglomeration of powder occurs and the porosity increases with an increase of the particle size of Ca-PZT. The incremental pore volume shows the presence of mesopores (30-100 $\AA)$ and macropores $(300 \AA)$ indicating particle growth during calcination.

\section{ACKNOWLEDGEMENTS}

To CNPq and CAPES for the financial support.

\section{REFERENCES}

[1] B. G. Muralidharan, A. Sengupta, G. S. Rao, D. C. Agrawal, Powders of $\mathrm{Pb}\left(\mathrm{Zr}_{\mathrm{x}} \mathrm{Ti}_{1-\mathrm{x}}\right) \mathrm{O}_{3}$ by sol-gel coating of $\mathrm{PbO}$, J. Mater. Sci. 30 (1995) 3231-3237. 
[2] A. P. Singh, S. K. Mishra, D. Pandey, Low-temperature synthesis of chemically homogeneous lead zirconate titanate (PZT) powders by a semi-wet method, J. Mater. Sci. 28 (1993) 5050-5055.

[3] N. Chakrabarti, H. S. Maiti, Chemical synthesis of PZT powder by auto-combustion of citrate-nitrate gel, Mater. Lett. 30 (1997) 169-173.

[4] H. Kanai, O. Furukawa, H. Abe, Y. Yamashita, Dielectric properties of $\left(\mathrm{Pb}_{1-\mathrm{x}} \mathrm{X}_{\mathrm{x}}\right)\left(\mathrm{Zr}_{0,7} \mathrm{Ti}_{0,3}\right) \mathrm{O}_{3}(\mathrm{X}=\mathrm{Ca}, \mathrm{Sr}, \mathrm{Ba})$ ceramics, J. Am. Ceram. Soc. 77, 10 (1994) 2620-2624.

[5] H. Nakashima, S. Hazumi, T. Kamiya, K. Tominaga, M. Okada, Electrical properties for capacitors of dynamic random access memory on $(\mathrm{Pb}, \mathrm{La})(\mathrm{Zr}, \mathrm{Ti}) \mathrm{O}_{3}$ thin films by metalorganic chemical vapor deposition, Jpn. J. Appl. Phys. 33 (1994) 5139-5142.

[6] K. Kakegawa, , J. Mohri, S. Shirasaki, K. Takahashi, Sluggish transition between tetragonal and rhombohedral phases of $\mathrm{Pb}(\mathrm{Zr}, \mathrm{Ti}) \mathrm{O}_{3}$ prepared by application of electrical field, J. Am. Ceram. Soc. 65, 10 (1982) 515-519.

[7] B. G. Muralidharam, A. Sengupta, G. S. Rao, D. C. Agrawal, Powders of $\mathrm{Pb}\left(\mathrm{Zr}_{\mathrm{x}} \mathrm{Ti}_{1-\mathrm{x}}\right) \mathrm{O}_{3}$ by sol-gel coating of PbO, J. Mater. Sci. 30 (1995) 3231-3237.

[8] N. Chakrabarti, H. S. Maiti, Chemical synthesis of PZT powder by alto-combustion of citrate-nitrate gel, Mater. Lett. 30 (1997) 169-173.

[9] M. P. Pechini, U. S. Patent 3.330.697 (1967).

[10] E. R. Leite, M. Cerqueira, L. A. Perazoli, R. S. Nasar, E. Longo, J. A. Varela, Mechanism of phase formation in $\mathrm{Pb}\left(\mathrm{Zr}_{\mathrm{x}} \mathrm{Ti}_{1-\mathrm{x}}\right) \mathrm{O}_{3}$ synthesized by a partial oxalate method, $\mathrm{J}$. Am. Ceram. Soc. 79, 6 (1996) 1563-1568.

[11] M. Cerqueira, R. S. Nasar, E. R. Leite, E. Longo, J. A. Varela, Synthesis and characterization of PLZT (9/65/35) by the Pechini method and partial oxalate, Mater. Lett. 35 (1998) 166-171.

[12] O. Yamaguchi, H. Mogi, Formation of zirconia titanate solid solution from alkoxides, J. Am. Ceram. Soc. 72, 6
(1989) 1065-1069.

[13] M. Cerqueira, Doctoral Thesis, UFScar, S. Carlos, Brasil (1996) 96pp.

[14] K. Kakegawa, K. Arai, Y. Sasaki, T. Tomizawa, Homogeneity and properties of lead zirconate titanate prepared by a combination of thermal spray decomposition method with solid-phase reaction, J. Am. Ceram. Soc. 71, 1 (1988) C49-C52.

[15] K. Kakegawa, J-I. Mohri, Synthesis of $(\mathrm{Ba}, \mathrm{Pb})(\mathrm{Zr}, \mathrm{Ti}) \mathrm{O}_{3}$ Solid solution having no compositional fluctuations, J. Am. Ceram. Soc. 68, 8 (1985) C204-C205.

[16] Y. Yoshikawa, K. Tsuzkui, T. Kobayashi, M. Takagi, Preparation of PLZT powders from several aqueous solutions, J. Mater. Sci. 23 (1988) 2729-2734.

[17] T. Yamamoto, Optimum Preparation methods for piezoelectric ceramics and their evaluation, Am. Ceram. Soc. Bull. 71, 6 (1992) 978-984.

[18] B. M. S. Song, D. Y. Kim, S. I. Shirasaki, H. Yamamura, Effect of excess $\mathrm{PbO}$ on the densification of PLZT ceramics, J. Am. Ceram. Soc. 72, 5 (1989) 833-836.

[19] K. Okasaki, K. Nagata, Effects of grain size and porosity on electrical and optical properties of PLZT ceramics, J. Am. Ceram. Soc. 56, 2 (1973) 82-86.

[20] A. I. Kingon, J. B. Clark, Sintering of PZT ceramics: II, Effects of PbO content on densification kinetics, J. Am. Ceram. Soc. 66, 4 (1983) 256-260.

[21] E. R. Leite, E. Longo, M. C. S. Cavaco, L. C. Carvalho, J. Avena, J. A. Varela, Third Euro-Ceramics Processing of Ceramics, Spain, Faenza Editrice S. L. vol. 1 (1993) 309.

[22] M. Cerqueira, R. S. Nasar, E. Longo, J. A. Varela, A. Beltran, R. Llusar, J. Andrés, Piezoelectric behaviour of PZT doped with calcium: A combined experimental and theoretical study, J. Mater. Sci. 32 (1997) 2381-2386.

[23] F. Kulcsar, Electromechanical properties of lead zirconate titanate ceramics modified with certain three or five valent addition, J. Am. Ceram. Soc. 42, 7 (1959) 343-49.

(Rec. 19/04/2007, Ac. 17/08/2007) 